NBER WORKING PAPER SERIES

\title{
ANOTHER BRICK ON THE WALL: ON THE EFFECTS OF NON-CONTRIBUTORY PENSIONS ON MATERIAL AND SUBJECTIVE WELL BEING
}

\author{
Rosangela Bando \\ Sebastian Galiani \\ Paul Gertler \\ Working Paper 28318 \\ http://www.nber.org/papers/w28318
NATIONAL BUREAU OF ECONOMIC RESEARCH
1050 Massachusetts Avenue
Cambridge, MA 02138
January 2021

The authors thank Juan Manuel Hernandez and Cesar Huaroto for providing key inputs and advice for this work. The authors declare that they have no financial or material interests in the results of this study. The views expressed herein are those of the authors and do not necessarily reflect the views of the National Bureau of Economic Research.

NBER working papers are circulated for discussion and comment purposes. They have not been peer-reviewed or been subject to the review by the NBER Board of Directors that accompanies official NBER publications.

(C) 2021 by Rosangela Bando, Sebastian Galiani, and Paul Gertler. All rights reserved. Short sections of text, not to exceed two paragraphs, may be quoted without explicit permission provided that full credit, including $(\odot$ notice, is given to the source. 
Another brick on the Wall: On the Effects of Non-Contributory Pensions on Material and

Subjective Well Being

Rosangela Bando, Sebastian Galiani, and Paul Gertler

NBER Working Paper No. 28318

January 2021

JEL No. I18,I3,I31

\section{ABSTRACT}

Public expenditures on non-contributory pensions are equivalent to at least 1 percent of GDP in several countries in Latin America and is expected to increase. We explore the effect of noncontributory pensions on the well-being of the beneficiary population by studying the Pensiones Alimentarias program established by law in Paraguay, which targets older adults living in poverty. Households with a beneficiary increased their level of consumption by 44 percent. The program improved subjective well-being in 0.48 standard deviations. These effects are consistent with the findings of Bando, Galiani and Gertler (2020) and Galiani, Gertler and Bando (2016) in their studies on the non-contributory pension schemes in Peru and Mexico. Thus, we conclude that the effects of non-contributory pensions on well-being in Paraguay are comparable to those found for Peru and Mexico and add to the construction of external validity.

Rosangela Bando

Inter-American Development Bank

1300 New York Avenue N.W.

Washington, DC 20577

rosangelab@iadb.org

Sebastian Galiani

Department of Economics

University of Maryland

3105 Tydings Hall

College Park, MD 20742

and NBER

galiani@econ.umd.edu
Paul Gertler

Haas School of Business

University of California, Berkeley

Berkeley, CA 94720

and NBER

gertler@haas.berkeley.edu 


\section{Introduction}

While pensions are believed to be critical for protecting material well-being after retirement, only 20 percent of seniors worldwide receive pension benefits (PallaresMiralles, Romero and Whitehouse, 2012). For those who have coverage, the benefits are often inadequate (ILO, 2014; Gasparini et al., 2007). Additionally, poverty rates among the elderly are substantially higher in countries where social security coverage is limited; the number of people who are 60 years of age or older is estimated to double by 2050 (United Nations, 2013); and the life expectancy of the elderly is also estimated to substantially increase by 2050 (Bosch, Melguizo and Pagés 2013). For these reasons, improving the effectiveness of pensions and expanding pension programs compel immediate attention.

Several governments have responded to high poverty rates among the elderly with noncontributory pensions. In OECD countries, 59 percent of the income of individuals over age 65 comes from public pension transfers (OECD, 2015). In Latin America, at least 15 countries have implemented non-contributory pension programs covering about 20 percent of the region's population (Bosch, Melguizo and Pagés, 2013; Pallares-Miralles, Romero and Whitehouse, 2012). In Latin America, these programs constitute a large part of social safety nets. For example, in Mexico, the Adultos Mayores program is the second largest social program behind the conditional cash transfer program Progresa (formerly Oportunidades). In Peru, Pension 65, a non-contributory pension program for the elderly, is second only to the conditional cash transfer program Juntos (Rubio and Garfias, 2010; Aguila et al., 2013, MIDIS, 2012). In Paraguay, Pensión Alimentaria, is the largest social program (STP, 2018).

In this paper, we study the effects of Pension Alimentaria in Paraguay. The program's main goal is to provide economic security to persons who are 65 years of age or older and living in poverty. At the time this study was conducted, the program provided beneficiaries with US\$ 92 every month. Identification in our study relies on a randomized control trial. 
We explore program effects on labor market outcomes. The lack of economic security may not allow elders to afford retirement. We explore changes in household labor and expenditure. We also test whether the transfer had impacts on physical health or subjective well-being. Evidence from Mexico and Peru show non-contributory pensions improve well-being by allowing beneficiaries to reduce work for pay while increasing consumption (Galiani, Gertler and Bando, 2016; Bando, Galiani and Gertler, 2020). Other studies have documented pensions may improve well-being by devoting time to pleasant activities (Knabe et al., 2010; Krueger and Muller, 2012; and Ruhm, 2001). Evidence also favors the idea that elders enjoy sharing transfers with other family members (Gertler et al., 2012, Duflo, 2003). Thus, we also test if the program resulted in benefits to other household members.

We find that households with a beneficiary increased their level of consumption by 44 percent and that the program reduced the proportion of older adults doing paid work by 4 percentage points. These effects contributed to their subjective welfare as indicated by a 0.48 standard deviation increase on a well-being index. The well-being index is composed of the depression scale (which itself decreased 7 percentage points), reported satisfaction with quality of life, empowerment, feeling of contribution to the expenditures common to all household members, and perception of self-worth. Beneficiaries reported suffering less illnesses (a decrease of 6 percentage points) and perceived better health (an of 8 percentage points for good or very good health). However, we do not find impacts on the use of health services, enrollment of minors in school or household composition. Finally, we find that transfers from persons residing outside the household decreased (a decrease of 8 percentage points) and transfer to persons residing outside the household increased (an increase of 34 percentage points).

Several studies have focused on the effects of non-contributory pension schemes on the health and material welfare of beneficiaries. Some examine the effects of such schemes on consumption (Martinez et al., 2020; Fan, 2010; Blau, 2008; Case and Deaton, 1998), physical and mental health (Alzua et al., 2019; Tae-Young, 2020; Kadir and Barret, 2014; Lingguo et al., 2018), and labor supply (Alzua et al., 2019; Chen and Jin Tan, 2018; 
Borrella-Max, 2019; Martinez et al., 2020; de Carvalho, 2008; Bosch, Melguizo and Pagés, 2013; Grueber and Wise, 1998). Other studies have analyzed the effects of pensions on other family members. For example, Case and Deaton (1998), Duflo (2003), Hamoudi and Thomas (2014) and Fan (2010) explore program effects on children's school enrollment, household composition and private transfers. Our work is also related to the work of Finkelstein et al. (2012) and Baicker et al. (2013) who find access to Medicaid health insurance lowered self-reported depression in low-income adults. Indeed, the literature shows unemployment results in more depression because of the lack of work, but also in less depression as people can spend more time in pleasant activities (Knabe et al., 2010; Krueger and Muller, 2012; and Ruhm, 2001).

In contrast, in previous work, we took a comprehensive approach in examining the influence of Peru's and Mexico's non-contributory pension schemes of Pensión 65 and Adultos Mayores on both material and subjective well-being (Bando, Galiani and Gertler, 2020; Galiani, Gertler and Bando, 2016). Indeed, pensions may allow older adults to reduce their time working and increase their time enjoying life. We found that beneficiaries used part of the transfer to finance an increase in household consumption and used the rest to offset reduction in labor earnings from beneficiaries reducing paid work. These changes resulted in an improvement in mental health as measured by the Geriatric Depression Scale. ${ }^{1}$

When we compare the results in this paper with the effects of the Pension 65 and Adultos Mayores program in Mexico, we find that, qualitatively, we can broadly generalize the estimates for Mexico and Peru to Paraguay. We find that the effects of the programs are not that different across the three countries. The depression score in Paraguay decreased by 6.90 percent, while it decreased by 8.68 percent in Peru and by 9.11 percent in Mexico. Paid work decreased by 4 percentage points in Paraguay and Peru, and 5 percentage points in Mexico. In addition, consumption rose by 44 percent in Paraguay, by 40 percent in Peru and by 14 percent in Mexico. For food consumption, households in

\footnotetext{
${ }^{1}$ Mental health is a widely accepted indicator of quality of life among the elderly (Campbell et al., 1976; Walker, 2005).
} 
Paraguay allocated 69 percent of the increase, while they allocated 67 percent in Peru and 54 percent in Mexico.

This study is important in that it provides one of the first experimental assessments on the impact of non-contributory voluntary contributions. The studies by Gertler, Galiani, and Bando (2016) in Mexico exploited within region variability for identification while Bando, Galiani, and Gertler (2020) in Peru relied on a regression discontinuity approach. Many other evaluations on the effects of non-contributory pensions have relied on this approach such as those used for evaluations in Taiwan by Fan (2010), in Bolivia by Borrella-Mas, Bosch and Sartarelli (2010), and in El Salvador by Martinez et al., (2020). Other evaluations have relied on difference-in-difference approaches such as those in South Korea by Tae-Young (2020), and Singapour by Chen and Jin Tan (2018). To our knowledge, the only one other experimental assessment of non-contributory pensions is the study of Alzua et al., (2019) in the state of Ekiti in Nigeria.

In addition to contributing to strengthen the internal validity of evidence on the effects of non-contributory pensions, this study contributes to construct external validity. ${ }^{2}$ As sciences mature, greater weight should be placed on evidence on multiple studies (see, among others, List, 2020).

In principle, the effects of any program are contingent on the context of the study (Angrist, J., 2004; Campbell, 1969; Fisher, 1935). Understanding program effects in multiple economic and cultural contexts is necessary to construct external validity and inform policy. Several studies use similar multi-country strategies to generalize causeand-effect constructs. For example, Cruces and Galiani (2007) examine the effects of fertility on labor outcomes in three counties, Banerjee et al. (2015) study microcredit in six countries, Gertler et al. (2015) study health promotion in four countries, Dupas et al. (2016) examine the effects of opening savings accounts in 3 countries, and Galiani et al.

\footnotetext{
${ }^{2}$ See Bo and Galiani (2019) for formal definitions of external validity.
} 
(2016) investigate slum upgrading in three countries. As List (2020) puts it: "Rome was not built in one day". ${ }^{3}$

This paper is organized as follows. Section II describes the Pension Alimentaria program. Section III describes the data, and section IV describes the identification strategy. Section $\mathrm{V}$ presents the empirical results. Section VI compares our findings with the results obtained in Peru and Mexico. Section VII concludes.

\section{The Pensiones Alimentarias Non-Contributory Pension Program}

The program provides beneficiaries with a monthly pension of a quarter of the minimum salary, which was equivalent to about US\$ 92 (Law N. 3728-2009). ${ }^{4}$ The program targets those persons 65 year old or older which live under the poverty line and do not have access to other mechanisms to ensure a minimum income. While $32 \%$ of the 327 thousand persons 65 years old or older were in poverty in 2009, non-contributory pensions covered only 16 percent. The program expanded its coverage to reach 42 percent of the population 65 years old or older (Ministerio de Hacienda, 2019).

To be eligible, a person must be of Paraguayan nationality and reside in Paraguayan territory, must not be receiving any economic benefits in the field of Social Security (social insurance, does not include medical insurance), must not be receiving any income from the Public or Private Sector, such as salaries, pensions, allowances, conditional transfers, or any other type of remuneration from these sectors, must accept the duties established in the Law and its regulations for granting the pension as a subsidy, and must not be serving or have pending sentence with final and executory conviction.

Beneficiaries contact the municipal government to request the program. On a second step, government officials make a physical visit to the household to check for living

\footnotetext{
${ }^{3}$ List (2020) cites the work of Francis Bacon, Novum Organum, which demands researchers slowly build an essential base of knowledge from the ground up, one experiment at a time.

${ }^{4}$ The exchange rate in May of 2018 was $\$ 5,734.94$ per US\$1 (Banco Central del Paraguay, 2020

[Retrieved 09/28/2020]). The minimum salary in July of 2018 was $\$ 2,112,562$.
} 
conditions. On a third step, program officials verify all eligibility requirements are met. Finally, eligible persons receive a bank transfer through the Banco Nacional de Fomento (BNF).

The targeting criteria to assess the living conditions of the household changed in December of 2016 to proceed with a more efficient data collection process. Before 2017, the ICV (Indice de Calidad de Vida) score used a multidimensional model that incorporated income, structural poverty, vulnerability, disability, and dependence of Senior Citizens. Starting 2017, the Technical Planning Secretariat applied a means tested score denominated STP (Secretaria de Técnica Planificación) scores. The STP score was adjusted and thus, there are two versions of the STP scores denominated score A and score B.

\section{Data Sources}

The data used in this study come from a survey carried out by the Innovation for Poverty Action lab non-profit organization. The survey was designed to evaluate Pensiones Alimentarias. The sampling frame aimed to identify 3,000 eligible individuals through random stratified selection on 15 of 17 departments. The departments of Amabay, Boquerón, and Alto Paraguay were excluded because the Census data indicated only 1 percent of the senior citizen population lived there. Three strata were based on whether the beneficiary was male or female, and whether the household was located in a rural or urban location. Among urban households, half were selected from urban districts and half among the greater Urban Area districts. ${ }^{5}$ The sampling frame resulted in a sample composed of beneficiaries out of which 50 percent are male and 50 percent are female, 50 percent live in rural areas and 50 percent in urban areas. The respondent of the survey was chosen at random when more than one person was eligible for the program within a household.

\footnotetext{
${ }^{5}$ These districts included Asunción, Ciudad del Este, Encarnación, and all districts from the Central Department.
} 
Data was collected between July of 2017 and November of 2018, approximately a year after beneficiaries started receiving benefits. The sample was designed to survey 3,000 identified but living conditions were assessed for 2,968 eligible individuals. However, 17 percent of individuals rejected to answer the survey, were absent, were unfit to respond, were deceased, or not found. Data was collected on a sample of 2,473 individuals.

The survey was designed to be answered by an older adult and the household head in about one hour each. The survey aimed to assess physical and mental health, employment, consumption among other items. To ease comparability, the survey included items used to evaluate the Adultos Mayores and Pensión 65 y más noncontributory programs in Mexico and Peru.

The survey questions were designed to collect detailed information on eligible older adults. The survey also collected basic information on other household members, including labor market participation, hours worked and monetary compensation for persons 14 years of age or older. The survey included a series of questions to assess the cognitive health of the respondent.

The survey also collected data on perceptions about life satisfaction, empowerment, contribution to household expenditures and self-worth. We use the weighted average of these data to build an index. The index is standardized relative to the distribution in the control group.

The survey collected information on food and non-food expenditure. Online Appendix A includes definitions for all the variables used in this study. All variables have nonmissing values for at least 93 percent of the observations, except for memory. The share of missing values is 17 percent but not related to treatment $(p$-value $=0.268)$.

\section{Identification Strategy}

To identify the impact of the program on the outcomes of interest, we rely on a stratified randomized control trial (RCT) approach. Within strata, individuals received treatment 
with equal probability $(\mathrm{p}=0.500)$. Online appendix B includes a map showing the allocation of beneficiaries in the country. We estimate the following empirical model to assess program impacts:

$$
y_{i s}=\eta_{s}+\beta T_{i s}+\varepsilon_{i s}
$$

where $y_{i s}$ is the outcome for individual $i$ in strata $s, T_{i s}$ denotes treatment status and varies at the individual level, and $\varepsilon_{i s}$ denotes an error term. The term $\eta_{s}$ denotes a strata fixed effect. We cluster errors at the strata level.

A threat to the identification of program effects is attrition. It was not possible to gather data on 15 percent of the sample. The share was statistically higher among the targeted individuals in the treatment group (18 percent of treatment individuals and 12 percent among of control individuals, $\mathrm{p}=0.000$ ). We focus the main analysis on 54 out of the 66 districts were attrition did not threat the RCT design. This subsample is composed of 1,939 individuals representing 78 percent of the 2,473 households which responded to the survey. The mean in characteristics across observations in the sample are not statistically different from those excluded. We repeat the analysis on the full sample in the robustness check section. We find results consistent with those estimated based on the restricted sample.

\section{Descriptive Statistics and Balance}

In this section, we provide descriptive statistics of the study population and investigate balance. Table 1 reports the means of individual and household head characteristics for the control group and differences in the means of the treatment and control groups. Column (1) reports the means for the control group. The individual and household characteristics reflect the targeting criteria. The individuals are on average 72 years old, 47 percent are male, 40 percent are married, and have 2 years of education. The household heads are on average 65 years old reflecting that a high percentage of individuals are both eligible are heads of the household, 40 percent are male, 47 percent 
are married, and have 2 years of schooling. Twenty nine percent of household had children ages 3 to 15 years old. Column (2) reports the difference of the treatment and control group means and column (3) shows p-values for tests of the null hypothesis of equal means estimated using the fixed effects model described by equation 1 . The experimental design resulted in no statistically significant differences among treatment and control groups.

\section{[Insert Table 1 Here]}

\section{Empirical Results}

In this section we present estimates of the impact of non-contributory pensions on labor supply, health, well-being, and consumption. We start out by discussing our preferred specification. More specifically, we focus on the average treatment effect estimates estimated by the restricted sample and with strata fixed effects. We then discuss how our results vary when estimation is based the full sample in the before last subsection.

\section{a. Labor Supply}

Table 2 reports the results for labor market participation. Column (1) shows averages among individuals in the control group, column (2) show differences between treatment and control groups controlling for strata fixed effects, and column (3) shows p-values adjusted for the family-wise error rate from multiple hypothesis testing following the procedure presented in Anderson (2008). ${ }^{6}$ The adjusted $p$-values control for the probability of false rejection for the family of outcomes listed within each table.

These results indicate that the program did not affect labor supply or hours worked. The share of individuals working remained at 35 percent. The number of hours worked in the previous week remained at 7.06. However, the receipt of pensions decreased work for

\footnotetext{
${ }^{6}$ We use FDR p-values. Anderson (2008) also uses FWER p-values to correct for multiple hypotheses tenting. We find little differences among the two types of correction given the small number of hypotheses tested in our paper.
} 
pay by 29 percent (from 14 to 10 percent). Labor earnings remained at US\$ 22.78. These findings are consistent with an increase in unpaid work in the household.

[Insert Table 2 here]

\section{b. Health and Well-Being}

Table 3 shows the results for health and well-being. The values of program estimates given in Column (2) for Panel A show that physical health was not affected. More specifically, the share of adults which reported illness in the last month decreased in 6

percentage points (from 62 to 56 percent). Consistent with this finding, older adults felt that their health had improved. The share of older adults with perception of good or very good health increased from 39 to 47 percent. The perception of older adults that they were having less difficulty than before in performing daily activities did not change and remained at 21 percent.

Table 3 Panel B, which focuses on subjective well-being, shows a consistent story. The program reduced the older adults' score on the Geriatric Depression Scale by 6.85 percent (from 0.58 to 0.54 ). In addition, the contribution-to-household expenditures score increased by 87.35 percent (from 0.52 to 0.97 ), the self-worth score rose by 20.55 percent (from 0.49 to 0.59 ). In addition, the satisfaction score increased by 5.09 percent (from 0.82 to 0.87 ), and the empowerment score increased in 17.14 percent (from 0.70 to 0.82 ). The overall well-being score, shown in the last row of Panel B, indicates that the program led to an increase in well-being equivalent to 0.48 standard deviations. Thus, the pension transfer may allow older adults to carry out non-paid work and enjoy life.

\section{[Insert Table 3 Here]}

The program did not incorporate any health insurance component. Consistent with this, the share of older adults affiliated with health insurance remained at 10 percent and there were few impacts on the use of health services. Primary care visits remained at 29 percent, the share which reported seeing a doctor, purchasing medication, or having a test remained at 64 percent. The share of adults which report having been hospitalized or 
having had surgery remained at 15 percent. However, we find the share of older adults which reported having dental, ophthalmological, or optometric care increased in 16.17 percent (from 0.32 to 0.38 percent). Table 4 reports estimates of program effects on health perception, insurance and health services.

[Insert Table 4 Here]

\section{c. Household Income and Consumption}

Table 5 reports impact estimates for household labor income and consumption expenditures, with income and expenditures being presented in US dollars (US\$) and in terms of adult equivalents. Column (2) shows that the program did not affect total household labor income. Indeed, total labor income remained at US\$ 42.66. The program did not affect labor income when excluding older adults either, which remained constant at US\$ 31.85. However, the program increased household expenditure by 43.73 percent (from US\$ 57.74 to US\$ 82.99). Older adults allocated 69 percent of their expenditure to food consumption and 31 percent to non-food consumption.

To get a sense of how these changes relate to the pension transfers, consider the following. The program transferred US\$ $92(528,141$ Guaranies $(\varnothing))$ per month per person. Considering that the average household size is 2.84 and additionally that, on average, the sample includes 1.29 older adults per household, the average transfer per adult equivalent to each household was US\$ 92/2.87 = US\$ 32.06. This amount is statistically different from the increase in consumption of US\$25.25 ( $p=0.000)$.

[Insert Table 5 Here]

\section{d. Benefits to Other Family Members and Transfers}

Increases in household consumption may benefit other household members, in addition to the older adults. Thus, we seek to determine if the pension transfer affected school enrollment, where we define this outcome variable as the percentage of household members who are 3 to 15 years old and enrolled in an educational institution. Table 6 in Panel A shows the results of this analysis. No effects were found. 
We then look at whether pensions influence living arrangements. As may be seen from the same panel, we do not find any effects on household size. Next, we try to determine if transfers at the older-adult and/or household-level change. Panel B shows impact estimates for current transfers at the household level. The share of households with individuals who report having received a transfer in the previous six months decreases from 22 percent to 14 percent. We also find the share of older adults which received a transfer decreased from 78 to 70 percent, but the share which sent a transfer increased from 24 to 58 percent. Thus, pension transfers may be offsetting dependence of the household from transfers and promoting support to other family members who live out of the household.

\section{[Insert Table 6 Here]}

\section{d. Robustness Tests}

In this section, we discuss the sensitivity of our results to the inclusion of all observations. In summary, our findings are robust. We compare the results just discussed with those estimated on the full sample. We find the coefficients are not statistically different to those discussed. We find impacts very similar in magnitude and significance. Tables that compare these estimates with our evaluation sample estimates are found in Online Appendix C. Thus, we conclude our results rely on the exogenous variation introduced by the experimental design and attrition did not threat the identification of program effects.

\section{Generalizing the Results}

Our study is restricted to older individuals living in poverty in 66 departments in Paraguay. Our study also applies to individuals aged 65 and older. In 2018, the population of people 65 years old or older represented 6.4 percent of the population (ECLAC,2020). However, this share is expected to increase to 7.7 percent by 2025 (ECLAC,2020). 
Our findings are consistent with evidence found in similar contexts. Our findings on labor supply are consistent with those documented for Brazil in 1991 by de Carvalho (2008) and for El Salvador in 2013 by Martinez et al. (2020) who find beneficiaries of old-age pensions decreased their labor force participation in thirty-eight and three percentage points, respectively. ${ }^{7}$

We also find the pension transfer leads to increases in consumption as in Fan (2010) in Taiwan who finds that in Taiwan transfers increased consumption by about 20 percent, Martinez (2020) in El Salvador who finds that El Salvador transfers increased consumption by 9 percent. Our finding on physical health is consistent to that in Kadir and Barret (2014) for Australia and Cheng et al., (2018) for China. Our findings on benefits to children in the household differ from those in Duflo (2003), but our findings on transfers to other family members are consistent to those of Hamoudi and Thomas (2014) for South Africa. Hamoudi and Thomas (2014) find that the receipt of pensions did influence transfers. We find evidence that the receipt of these pensions leads to a decrease in transfers received and an increase in transfer made. Our results on transfers are also like those of Fan (2010) in Taiwan, who finds that pension transfers translate into decreases in private transfers to the elderly equivalent to 39 cents for every pension dollar. The receipt of a pension is likely to benefit family members who reside elsewhere. This finding contrast with that of Peru and Mexico where the programs had no impacts on transfers.

Though informative, these contrasts among programs have important limitations in that there are differences in the programs as well as in the measure of outcomes across studies. To better assess the generalizability of the results in our study, we now compare our findings with those of Bando, Galiani and Gertler (2020) and Galiani, Gertler and Bando (2016). Even though the programs in these studies are not identical, they tend to show important similarities. In addition, we can describe both similitudes and differences

\footnotetext{
${ }^{7}$ This finding is not generalizable to other age groups. Banerjee et al. (2017) finds cash transfers do not discourage overall paid work.
} 
with precision in many dimensions (List, 2020). We assess impacts on labor outcomes, consumption, physical and mental health, and transfers to other family members.

The Pensiones Alimentarias program in Paraguay, the Pension 65 program in Peru, and the Adultos Mayores program in Mexico have three main features in common. First, all are federal programs intended to provide social security coverage to the elderly in poor areas. Second, all programs have minimum eligibility requirements, since they both target persons above a set age threshold who are living in poverty. Third, all programs provide regular non conditional cash transfers.

However, the programs differ in three important ways as well. First, both Peru and Mexico provided bi-monthly transfers of similar amounts (at the time these studies were conducted, the bi-monthly transfer in Mexico was equivalent to US\$95, while it was equivalent to US\$ 78 in Peru), while Paraguay provided a monthly transfer of US\$ 92. Second, the Mexican government initially implemented the Adultos Mayores program only in rural areas (see Galiani, Gertler and Bando (2016) for an evaluation of the program's implementation in rural localities with fewer than 2,500 habitants). Over time, however, Adultos Mayores was expanded to urban areas. The Paraguayan and the Peruvian governments, on the other hand, did not introduce any geographic restrictions based on population size. Third, until the 2013 fiscal year, individuals in Mexico did not become eligible for the Adultos Mayores program until they reached 70 years of age, whereas, in Paraguay and Peru, people became eligible at age 65 ever since its inception.

In summary, we find that the results in the three countries are qualitatively similar: The Geriatric Depression Scale scores in Paraguay decreased in 6.85 percent, while in Peru and Mexico it decreased by 8.68 and 9.11 percent, respectively. Paid work decreased by 4 percentage points in Paraguay and Peru, and in 5 percent in Mexico. Consumption rose by 44 percent in Paraguay, 40 percent in Peru, and 14 percent in Mexico. In Paraguay, Peru, and Mexico, a share of 69 percent, 67 percent, and 54 percent of the increase in consumption was allocated to food, respectively. Figure 1 illustrates the comparison of the consumption, depression and labor variables in Mexico and Peru. 


\section{[Insert Figure 1 Here]}

The three populations have many similarities. The average age of the beneficiaries is around 72 years in all three countries, and approximately half of the population is male. Household consumption per adult is equivalent to US\$ 58 for Paraguay, US\$ 45 for Peru and US\$ 40 for Mexico. There were some significant differences between these sample populations, however. The program in Mexico targeted rural populations, while the programs in Paraguay and Peru did not. The sample for Paraguay however over represents the rural population as it is composed of 50 percent rural households, while 40 percent of the population lives in rural areas (OECD, 2018). As a result, the households in the sample for the Mexican study were larger, and the education level of the older adults was lower in the Paraguayan and Mexican sample populations. Another difference was that 59 percent of older adults work in Peru, while the corresponding figure was only 36 percent in Mexico and 35 percent in Paraguay. Despite these differences, the labor impact of non-contributory pension systems is similar in magnitude in the three countries but is smaller as a percentage of initial outcomes in Paraguay and Peru than it is in Mexico.

The three surveyed populations are similar in terms of the age and gender of older adults, as well as household consumption levels. However, there are some significant differences between the three populations that need to be identified, as they allow us to learn how the effects of non-contributory pensions vary in different contexts. We identify two main differences. First, the percentage of older adults who are working for pay is larger in Peru (51 percent of older adults reported having worked in the previous week), relative to Mexico (23 percent) and Paraguay (14 percent). Accordingly, older adults' labor earnings amount to US\$ 23 in Peru and Paraguay and US\$ 16 in Mexico. The programs in Paraguay, Peru and Mexico triggered a decrease of around four percentage points in paid work. This change represents a 29 percent decrease (from 14 to 10 percent) in Paraguay, a 20 percent decrease (from 23 percent to 18 percent) in Mexico, but a decrease of only nine percent in Peru (from 51 percent to 46 percent). 
In addition, the household size in terms of adult equivalents is larger in Mexico, where an average household has 5.6 adult equivalents, while a household has 3.2 adult equivalents in Peru and 2.9 in Paraguay. ${ }^{8}$ The average older adult in Peru has four years of education, while the average older adult in Paraguay or Mexico have one and two years, respectively. These differences may, in part, be a result of the difference in targeting criteria and sampling, since the Adultos Mayores program in Mexico targets rural populations and the Pensión Alimentaria oversamples rural beneficiaries in Paraguay, while Pension 65 in Peru does not.

We conclude that the results for Paraguay contribute to our knowledge about the effects of non-contributory pensions and allow us to apply that knowledge to yet a different context. Despite contextual differences across the three countries, we observe a decrease in work for pay, improvements in subjective well-being and an increase in consumption. The evidence suggests that the findings of Galiani, Gertler and Bando (2016) in rural Mexico and Bando, Galiani and Gertler (2020) in well-being and consumption can be reasonably well generalized to Paraguay in qualitative terms.

\section{Conclusions.}

To study the effects of non-contributory pensions in Paraguay, we exploit a randomized control trial, and thus, this study provides a strong identification strategy. We find improvements in mental health resulting from reduced paid work and an increase in consumption assessed via regression discontinuity approaches are confirmed by experimental evidence. We find that the receipt of non-contributory pensions in Paraguay benefited older adults in several ways. For instance, it led to improvements in physical and mental health, as evidenced by a decrease of 6 percentage points in reported illness and an increase of 0.48 standard deviations in the subjective well-being index. We do not find impacts on the use of health services or labor. The bulk of the cash transfer was used

\footnotetext{
${ }^{8}$ This implies the transfer in Paraguay (US\$92/2.9) and Peru (US\$78/3.2) were 91 and 44 percent larger than that in Mexico (US\$95/5.6).
} 
to finance an increase in consumption of 44 percent. In addition, recipient households are more likely to support members who reside elsewhere, as the share of households that made transfers to other individuals or households increased from 24 to 58 .

More importantly, we find that our results in subjective well-being and consumption are qualitatively like those of Bando, Galiani and Gertler (2020) and Galiani, Gertler and Bando (2016) in Peru and Mexico and hence these sets of results help us to construct external validity on the effects of non-contributory pensions on material and subjective well-being. 


\section{References}

Abhijit V. Banerjee, Rema Hanna, Gabriel E. Kreindler, Benjamin A. Olken, 2017. "Debunking the Stereotype of the Lazy Welfare Recipient: Evidence from Cash Transfer Programs," World Bank Research Observer, World Bank Group, vol. 32(2), pages 155-184.

Aguila, Emma, Nelly Mejía, Francisco Pérez-Arce, Alfonso Rivera, . 2013. "Programas de pensiones no contributivas y su viabilidad financiera." (Rand WR-999).

Alzua, Maria Laura, Natalia Cantet, Ana Dammert and Damilola Olajide, 2019. "Welfare Effects of a Non-Contributory Old Age Pension: Experimental Evidence for Ekiti State, Nigeria," Working Papers PIERI 2019-15, PEP-PIERI.

Anderson (2008), "Multiple Inference and Gender Differences in the Effects of Early Intervention: A Reevaluation of the Abecedarian, Perry Preschool, and Early Training Projects", Journal of the American Statistical Association, 103(484), $1481-1495$

Angrist, J., 2004, "Treatment Effect Heterogeneity in Theory and Practice," Economic Journal. 114 (494), C52-C83.

Baicker, K., Taubman, S., Allen, H., Bernstein, M., Gruber, J., Newhouse, J., Schneider, E.,Wright, B., Zaslavsky, A., Finkelstein, A., 2013. The Oregon experiment effects of Medicaid on clinical outcomes. N. Engl. J. Med. 368, 1713-1722.

Bando, Rosangela, Sebastian Galiani and Paul Gertler, 2020. "The Effects of Noncontributory Pensions on Material and Subjective Well-Being," Economic Development and Cultural Change, University of Chicago Press, vol. 68(4), pages 1233-1255.

Banerjee, A., Karlan, D. and Zinman, J. 2015. "Six Randomized Evaluations of Microcredit: Introduction and Further Steps.” American Economic Journal: Applied Economics 7(1): 1-21.

Blau, David M. 2008. "Retirement and Consumption in a Life Cycle Mode.," Journal of Labor Economics. University of Chicago Press. Volume 26, pp. 35-71.

Bo, Hao and Sebastian Galiani, 2019. “Assessing External Validity', NBER WP 26422.

Borrella-Mas, Miguel Angel, Mariano Bosch and Marcello Sartarelli, 2019. "Heterogeneous Effect of a Non-contributory Pension. Evidence from Bolivia," Documentos de Trabajo del ICAE 2019-35, Universidad Complutense de Madrid, Facultad de Ciencias Económicas y Empresariales, Instituto Complutense de Análisis Económico.

Bosch, Mariano, Angel Melguizo, and Carmen Pagés. 2013. Better Pensions Better Jobs: Towards Universal Coverage in Latin America and The Caribbean. Washington: Inter-American Development Bank.

Campbell, A., Converse, P., Rodgers, W., 1976. "The Quality of American Life: Perceptions, Evaluations, and Satisfactions." vol. 3508. Russell Sage Foundation. 
Campbell, Donald T. 1969. "Reforms as Experiments." American Psychologist. Volume 24, pp. 409-429.

Case, A., Deaton, A., 1998. "Large cash transfers to the elderly in South Africa." Econ. J. $108,1330-1361$.

Chen, Yanying and Yi Jin Tan, 2018. "The effect of non-contributory pensions on labour supply and private income transfers: evidence from Singapore" IZA Journal of Labor Policy, Vol. 7(1), pages 1-54, December.

Cruces, Guillermo, and Sebastian Galiani. 2007. "Fertility and Female Labor Supply in Latin America: New Causal Evidence." Labour Economics. Volume 14, pp. 565573.

Dirección General de Estadística, Encuestas y Censos (DGEEC). 2019. "Paraguay. Proyeccionesde población nacional, áreas urbana y rural, por sexo y edad, 2019." Gobierno Nacional. Link [Last retrieved 09/30/2020].

de Carvalho Filho, Irineu Evangelista. 2008. "Old-age Benefits and Retirement Decisions of Rural Elderly in Brazil.” Journal of Development Economics. Volume 86, Issue 1, April, pp. 129-146. ISSN 0304-3878. http://www.sciencedirect.com/science/article/pii/S0304387807000946.

Duflo, Esther. 2003. "Grandmothers and Granddaughters: Old Age Pensions and Intrahousehold Allocation in South Africa." World Bank Economic Review. Volume 17, Issue 1, pp. 1-25. https://www.researchgate.net/publication/2895800_DOI_101093wberlhg013.

Dupas P., D Karlanł J Robinson and D Ubfal. 2016. "Banking the Unbanked? Evidence from three countries," NBER Working Paper No. 22463, National Bureau of Economic Research, Inc., Cambridge MA

Economic Commission for Latin America and the Caribbean (ECLAC). 2020. "Latin America and the Caribbean: Population estimates and projections." United Nations. Link [Retrieved 09/30/2020].

Fan, Elliott. 2010. "Who Benefits from Public Old Age Pensions? Evidence from a Targeted Program." Economic Development and Cultural Change. Volume 58, No. 2, pp. 297-322.

Finkelstein, A., Taubman, S., Wright, B., Bernstein, M., Gruber, J., Newhouse, J., Allen, H., Baicker, K., 2012. The Oregon health insurance experiment: evidence from the first year. Q. J. Econ. 127, 1057-1106.

Fisher, Ronald. 1935. The Designs of Experiments. London: Oliver and Boyd.

Galiani, Sebastian, Paul Gertler, Raimundo Undurraga, Ryan Cooper, Sebastian Martinez and Adam Ross. 2016. Forthcoming in the Journal of Urban Economics. October.

Galiani, Sebastian, Paul Gertler, and Rosangela Bando. 2016. "Non-Contributory Pensions." Labour Economics. Volume 38, January, pp. 47-58. ISSN 0927-5371. http://dx.doi.org/10.1016/j.labeco.2015.11.003. 
Galiani, S., Gertler, P. J. and Undurraga, R. 2015. "The Half-Life of Happiness: Hedonic Adaptation in the Subjective Well-Being of Poor Slum Dwellers to a Large Improvement in Housing," NBER Working Papers 21098, National Bureau of Economic Research, Inc., Cambridge MA

Gasparini, L., Alejo, J., Haimovich, F., Olivieri, S., Tornarolli, L., 2007. Poverty among the Elderly in Latin America and the Caribbean. CEDLAS.

Gertler, P., Martinez, S., Rubio-Codina, M., 2012. Investing cash transfers to raise longterm living standards. Am. Econ. J. Appl. Econ. 4, 164-192.

Gertler, P. M Shah, ML Alzua, L Cameron, S Martinez, S Patil, 2015 "How Does Health Promotion Work? Evidence From The Dirty Business of Eliminating Open Defecation” NBER Working Paper No. 20997, National Bureau of Economic Research, Inc., Cambridge MA

Gruber, J., Wise, D., 1998. Social security and retirement: an international comparison. Am. Econ. Rev. 88, 158-163.

Hamoudi, Amar, and Duncan Thomas. 2014. "Endogenous Coresidence and Program Incidence: South Africa's Old Age Pension.” Journal of Development Economics. Volume 109, July, pp. 30-37, ISSN 0304-3878. http://dx.doi.org/10.1016/j.jdeveco.2014.03.02 and http://www.sciencedirect.com/science/article/pii/S0304387814000327.

International Labour Organization (ILO). 2014. "Social Protection for Older Persons: Key Policy Trends and Statistics." Social Protection Policy Paper No. 11. Geneva: International Labour Organization (ILO).

Kadir, Atalay and Garry F. Barrett. 2014. "The Causal Effect of Retirement on Health: New Evidence from Australian Pension Reform. Economics Letters. Volume 125, Issue 3, December, pp. 392-395. ISSN 0165-1765. http://dx.doi.org/10.1016/j.econlet.2014.10.028.

Knabe, A., Rätzel, S., Schöb, R.,Weimann, J., 2010. Dissatisfied with life but having a good day: time - use and well - being of the unemployed. Econ. J. vol.120, 867 889.

Krueger, A., Mueller, A., 2012. The lot of the unemployed: a time use perspective. Journal of the European Economic Association vol. 10(4). European Economic Association, pp. 765-794 (08).

Lingguo, Cheng, Hong Liu, Ye Zhang and Zhong Zhao. 2018. "The health implications of social pensions: Evidence from China's new rural pension scheme," Journal of Comparative Economics, Elsevier, vol. 46(1), pages 53-77.

List, John, 2020. "Non Est Disputandum Generalizability? A glimpse into the external validity trial. NBER WP 27535.

Martinez, Sebastian, Michelle Pérez, Luis Tejerina, and Anastasiya Yarygina. 2020. Pensions for the Poor: the Effects of Non-contributory Pensions in El 
Salvador," Journal of Economics, Race, and Policy, vol. 3(1), pages 96-115, March.

Ministerio de Hacienda. 2019. "Informe Final de Resultados de la Evaluación de Impacto Social del Programa Pensión Alimentaria para Adultos Mayores en Situaciones de Pobreza." Ministerio de Hacienda, República de Paraguay. Link [Retrieved 09/28/2020].

Organization for Economic Cooperation and Development (OECD). 2018. Multidimensional Review of Paraguay. Volume 1. Initial Assessment. Link [Last retrieved October $\left.20^{\text {th }}, 2020\right]$.

Organization for Economic Cooperation and Development (OECD). 2015. "Pensions at a Glance 2015: OECD and G20 Indicators.” Paris: OECD Publishing. http://dx.doi.org/10.1787/pension_glance-2015-en.

Pallares-Miralles, Moserrat, Carolina Romero, and Edward Whitehouse. 2012. "International Patterns of Pension Provision II: A Worldwide Overview of Facts and Figures." Social Protection and Labor Discussion Paper No. 1211. The World Bank.

Rubio, Gloria, and Francisco Garfias. 2010. "Análisis Comparativo sobre los Programas para Adultos Mayores en México." Volume 161. Santiago: Economic Commission for Latin America and the Caribbean (ECLAC).

Ruhm, C., 2001. Economic Expansions are Unhealthy: Evidence from Microdata. National Bureau of Economic Research (No. w8447).

Secretaría Técnica de Planificación del Desarrollo Económico y Social (STP). 2018. "Noticias: Beneficiaron a más de 190.000 adultos mayores con pensión alimentaria". December 6th, 2018. República de Paraguay. Link. Retrieved October 14th, 2020.

Sheikh, J., Yesavage, J., 1986. Geriatric Depression Scale (GDS): recent evidence and development of a shorter version. Clin. Gerontol. J. Aging Ment. Health vol. 5, $165-173$.

Tae-Young, Pak. 2020. "Social protection for happiness? The impact of social pension reform on subjective well-being of the Korean elderly," Journal of Policy Modeling, Elsevier, vol. 42(2), pages 349-366.

United Nations. 2013. World Population Ageing 2013.. Department of Economic and Social Affairs, Population Division. United Nations Publication ST/ESA/SER.A/348.

Walker, Alan, 2005. A European perspective on quality of life in old age. Eur. J. Ageing 2, 2-12. Winkelmann, L.,

World Health Organization (WHO). 2008. "Waist Circumference and Waist-Hip Ratio. Report of a WHO Expert Consultation“ Geneva, December. 
World Health Organization (WHO). 2016. "Raised Blood Pressure. Situation and Trends.", Global Health Observatory (GHO) data.

http://www.who.int/gho/ncd/risk_factors/blood_pressure_prevalence_text/en/

Zhu, Rong, and Xiaobo He. 2015. How Does Women's Life Satisfaction Respond to Retirement? A Two-Stage Analysis. Economics Letters. Volume 137, December, pp. 118-122. ISSN 0165-1765. http://dx.doi.org/10.1016/j.econlet.2015.11.002 and http://www.sciencedirect.com/science/article/pii/S0165176515004528.

Figure 1. The effects of non-contributory pensions on mental health, labor performed by older adults and household consumption

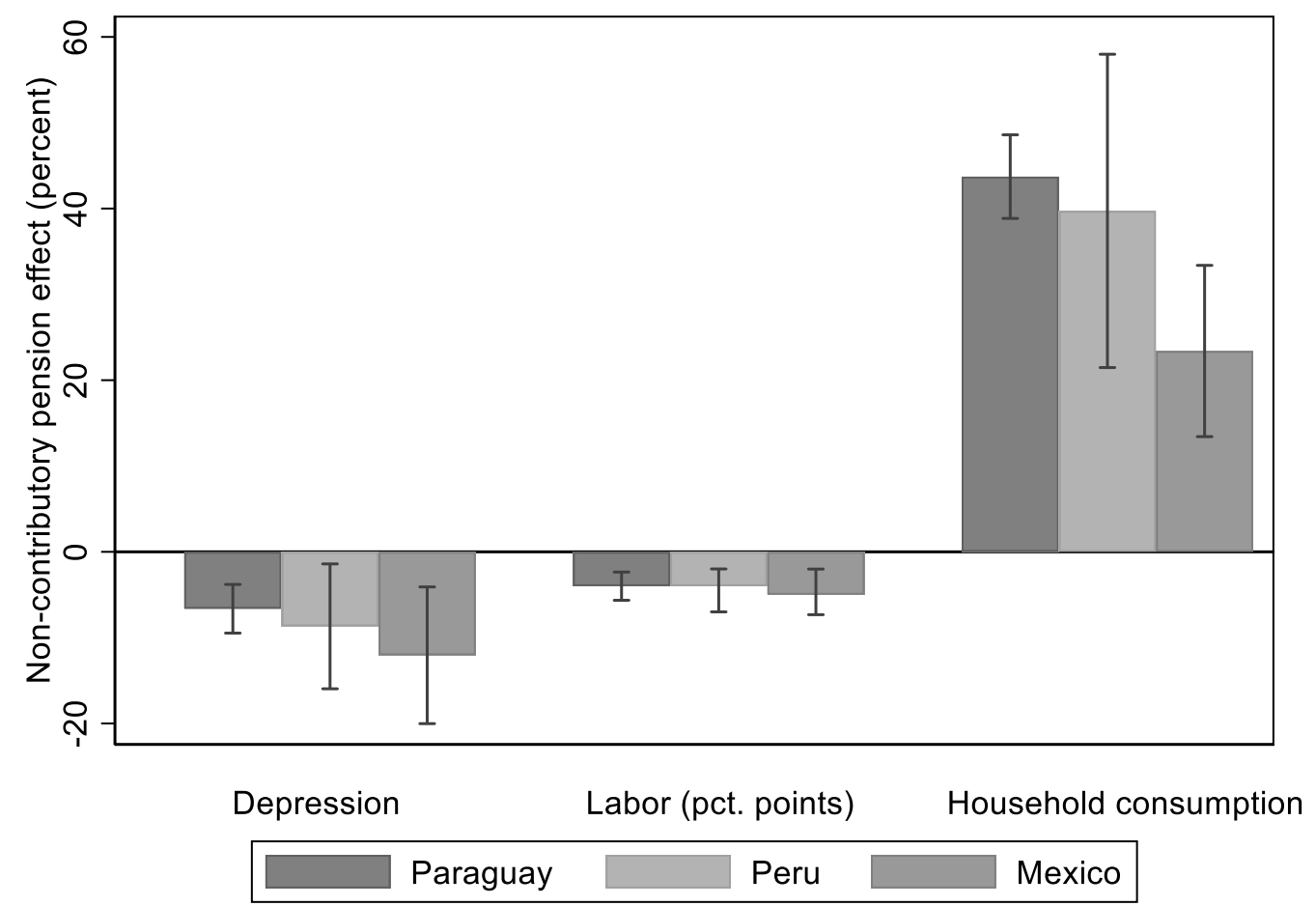

Source: Authors' calculations.

Note: The results for Mexico correspond to the effects of the Adultos Mayores program in that country. These effects are reported in Galiani, Gertler and Bando (2016). The results for Peru correspond to the effects of the Pension 65 program. These effects are reported in Bando, Galiani and Gertler (2020). The vertical axis shows the magnitude of point estimates. The thin lines show 90 percent confidence intervals. 
Table 1. Means and balance of individual variables

\begin{tabular}{|c|c|c|c|c|}
\hline & $\begin{array}{l}\text { Mean } \\
\text { control } \\
\text { group } \\
(1)\end{array}$ & $\begin{array}{c}\text { Difference } \\
\text { (Treatment } \\
\text { mean - } \\
\text { control } \\
\text { mean) } \\
(2)\end{array}$ & $\begin{array}{l}\text { Standard } \\
\text { error of } \\
\text { the } \\
\text { differenc } \\
\text { e } \\
(3)\end{array}$ & $\begin{array}{c}p \text {-value for } \\
\text { test of } \\
\text { equality } \\
(4)\end{array}$ \\
\hline \multicolumn{5}{|c|}{ Panel A. Older adult characteristics } \\
\hline Age & 72.77 & -0.04 & 0.22 & 0.853 \\
\hline Married & 0.40 & -0.03 & 0.03 & 0.282 \\
\hline Literate & 0.72 & 0.03 & 0.02 & 0.290 \\
\hline $\begin{array}{r}\text { Years of } \\
\text { schooling }\end{array}$ & 2.23 & -0.13 & 0.06 & 0.088 \\
\hline \multicolumn{5}{|c|}{ Panel B. Household head characteristics } \\
\hline Age & 65.05 & 0.18 & 0.61 & 0.779 \\
\hline Male & 0.40 & 0.02 & 0.02 & 0.463 \\
\hline Older adult & 0.69 & 0.02 & 0.01 & 0.122 \\
\hline Married & 0.47 & -0.02 & 0.03 & 0.526 \\
\hline $\begin{array}{r}\text { Years of } \\
\text { schooling }\end{array}$ & 4.10 & 0.10 & 0.21 & 0.649 \\
\hline $\begin{array}{r}\text { There are } \\
\text { children in the } \\
\text { household }\end{array}$ & 0.29 & 0.02 & 0.02 & 0.493 \\
\hline
\end{tabular}

Source: Authors' calculations.

Note: Based on 1,939 individuals, out of which 918 were allocated to treatment and 1,021 to control. Stratification imposed balance in the gender of the older adult (male or female), geographic location of the household (rural, urban, greater urban), and the score to assess the household living conditions (DNPC, STPA, or STPB). 
Table 2. Impact on individual labor supply

\begin{tabular}{|c|c|c|c|}
\hline & $\begin{array}{l}\text { Mean in } \\
\text { control } \\
\text { group } \\
(1)\end{array}$ & $\begin{array}{c}\text { Difference } \\
\text { between treatment } \\
\text { and control group } \\
\text { (2) }\end{array}$ & $\begin{array}{c}\text { Adjusted p-values } \\
\text { (3) }\end{array}$ \\
\hline \multicolumn{4}{|l|}{ Panel A. Work last week } \\
\hline Worked & 0.35 & $\begin{array}{c}0.00 \\
(0.02)\end{array}$ & 1.00 \\
\hline & & {$[0 \%]$} & \\
\hline Hours worked & 7.06 & $\begin{array}{c}-0.30 \\
(0.56) \\
{[-4.24 \%]}\end{array}$ & 0.824 \\
\hline \multicolumn{4}{|l|}{ Panel B. Paid work last week } \\
\hline \multirow[t]{2}{*}{ Worked } & 0.14 & $\begin{array}{c}-0.04 * * * \\
(0.01)\end{array}$ & 0.037 \\
\hline & & {$[-28.57 \%]$} & \\
\hline \multirow[t]{2}{*}{ Hours worked } & 3.49 & $\begin{array}{l}-1.21^{*} \\
(0.52)\end{array}$ & 0.122 \\
\hline & & {$[-34.67 \%]$} & \\
\hline \multirow[t]{2}{*}{ Labor Earning } & 22.78 & $\begin{array}{c}3.88 \\
(5.18)\end{array}$ & 0.824 \\
\hline & & {$[17.03 \%]$} & \\
\hline
\end{tabular}

Source: Authors' calculations.

Note: Based on 1,939 observations. Standard errors, clustered at the strata level, are shown in parentheses. Coefficients as percentages of the mean in the control group are shown in brackets. $P$-values adjusted according to Anderson (2008) for the family of outcomes listed in the table. *** indicate that the estimates coefficient has a statistically significant difference from zero at the 0.01 level. 
Table 3. Impact on health and well-being

\begin{tabular}{|c|c|c|c|}
\hline & $\begin{array}{l}\text { Mean in control } \\
\text { group } \\
\text { (1) }\end{array}$ & $\begin{array}{c}\text { Difference } \\
\text { between } \\
\text { treatment and } \\
\text { control group } \\
(2)\end{array}$ & $\begin{array}{c}\text { Adjusted } \\
p \text {-values } \\
(3) \\
\end{array}$ \\
\hline \multicolumn{4}{|l|}{ Panel A. Physical health } \\
\hline Illness in the last month & 0.62 & $\begin{array}{c}-0.06 \\
(0.02)^{* * *}\end{array}$ & 0.005 \\
\hline \multicolumn{4}{|c|}{ Panel B. Mental health and subjective well-being } \\
\hline Depression symptoms index & 0.58 & $\begin{array}{c}-0.04 \\
(0.01)^{* * *}\end{array}$ & 0.001 \\
\hline Satisfaction with quality of life & 0.82 & $\begin{array}{c}0.05 \\
(0.01)^{* * * *}\end{array}$ & 0.005 \\
\hline Empowerment & 0.70 & $\begin{array}{c}0.12 \\
(0.02)^{* * * *}\end{array}$ & 0.001 \\
\hline Contribution & 0.52 & $\begin{array}{c}0.45 \\
(0.03)^{* * * *}\end{array}$ & 0.001 \\
\hline Self-worth & 0.49 & $\begin{array}{c}0.10 \\
(0.01)^{* * * *}\end{array}$ & 0.001 \\
\hline Subjective well-being index & 0.00 & $\begin{array}{c}0.48 \\
(0.03)^{* * * *}\end{array}$ & 0.001 \\
\hline Memory & 11.78 & $\begin{array}{c}0.24 \\
(0.09)^{* *}\end{array}$ & 0.011 \\
\hline
\end{tabular}

Source: Authors' calculations.

Note: Based on 1,939 observations. Standard errors, clustered at the strata level, are shown in parentheses. Coefficients as percentages of the mean in the control group are shown in brackets. P-values adjusted according to Anderson (2008) for the family of outcomes listed in the table. ***,**** indicate that the estimates coefficient has a statistically significant difference from zero at the 0.01, 0.05 and 0.01 levels, respectively. 
Table 4. Impact on individuals' health perceptions, health insurance and use of health services

\begin{tabular}{|c|c|c|c|}
\hline & $\begin{array}{c}\text { Mean for } \\
\text { control } \\
\text { group } \\
(1)\end{array}$ & $\begin{array}{c}\text { Difference } \\
\text { between } \\
\text { treatment and } \\
\text { control group } \\
\text { (2) }\end{array}$ & $\begin{array}{c}\text { Adjusted } \\
p \text {-values } \\
(3)\end{array}$ \\
\hline \multirow[t]{2}{*}{$\begin{array}{l}\text { Perception of good or very good health ( } 1 \text { if yes, } \\
0 \text { otherwise) }\end{array}$} & 0.39 & $\begin{array}{c}0.08 \\
(0.01)^{* * *}\end{array}$ & 0.008 \\
\hline & & [21.27\%] & \\
\hline \multirow[t]{2}{*}{$\begin{array}{l}\text { Perception of difficulty performing daily } \\
\text { activities ( } 1 \text { if yes, } 0 \text { otherwise) }\end{array}$} & 0.21 & $\begin{array}{l}-0.02 \\
(0.01)\end{array}$ & 0.377 \\
\hline & & {$[-8.57 \%]$} & \\
\hline Health insurance (1 if insured, 0 otherwise) & 0.10 & $\begin{array}{c}0.03 \\
(0.02) \\
{[26.87 \%]}\end{array}$ & 0.377 \\
\hline \multirow[t]{2}{*}{ In the previous month had primary care visit } & 0.29 & $\begin{array}{l}-0.02 \\
(0.02)\end{array}$ & 0.516 \\
\hline & & {$[-8.14 \%]$} & \\
\hline \multirow[t]{2}{*}{$\begin{array}{l}\text { In the previous month had visit, medication or } \\
\text { exam }\end{array}$} & 0.64 & $\begin{array}{c}0.01 \\
(0.02)\end{array}$ & 0.516 \\
\hline & & {$[2.20 \%]$} & \\
\hline \multirow[t]{2}{*}{$\begin{array}{l}\text { In the previous } 3 \text { months had dental, } \\
\text { ophthalmological or optometric care or } \\
\text { vaccination }\end{array}$} & 0.32 & $\begin{array}{c}0.05 \\
(0.02)^{* *}\end{array}$ & 0.085 \\
\hline & & {$[16.17 \%]$} & \\
\hline \multirow[t]{2}{*}{$\begin{array}{l}\text { In the previous } 12 \text { months was hospitalized or } \\
\text { had surgery }\end{array}$} & 0.15 & $\begin{array}{l}-0.01 \\
(0.02)\end{array}$ & 0.516 \\
\hline & & {$[-6.38 \%]$} & \\
\hline
\end{tabular}

Source: Authors' calculations.

Note: Based on 1,939 observations. Standard errors, clustered at the strata level, are shown in parentheses. Coefficients as percentages of the mean in the control group are shown in brackets. P-values adjusted according to Anderson (2008) for the family of outcomes listed in the table. $* * *, * * *$ indicate that the estimates coefficient has a statistically significant difference from zero at the $0.01,0.05$ and 0.01 levels, respectively. 
Table 5. Impact on household income and expenditures

\begin{tabular}{|c|c|c|c|}
\hline & $\begin{array}{c}\text { Mean in } \\
\text { control } \\
\text { group } \\
(1)\end{array}$ & $\begin{array}{l}\text { Difference } \\
\text { between } \\
\text { treatment and } \\
\text { control group } \\
\text { (2) }\end{array}$ & $\begin{array}{c}\text { Adjusted } \\
p \text {-values } \\
\\
(3) \\
\end{array}$ \\
\hline \multirow[t]{2}{*}{ Labor income per adult equivalent (AE) } & 42.66 & $\begin{array}{c}2.31 \\
(56.23)\end{array}$ & 0.407 \\
\hline & & [5.41\%] & \\
\hline \multirow[t]{2}{*}{ Labor income per AE excluding older adult } & 31.85 & $\begin{array}{c}2.66 \\
(6.58)\end{array}$ & 0.407 \\
\hline & & [8.35\%] & \\
\hline \multirow[t]{2}{*}{ Household expenditure per AE } & 57.74 & $\begin{array}{c}25.25 \\
(2.04)^{* * *}\end{array}$ & 0.001 \\
\hline & & [43.73\%] & \\
\hline Household food expenditure per AE & 38.44 & $\begin{array}{c}17.37 \\
(1.89)^{* * *}\end{array}$ & 0.001 \\
\hline \multirow{3}{*}{ Household non-food expenditure per AE } & & {$[45.19 \%]$} & \\
\hline & 19.31 & $\begin{array}{c}7.87 \\
(1.71)^{* * * *}\end{array}$ & 0.003 \\
\hline & & {$[40.76 \%]$} & \\
\hline
\end{tabular}

Source: Authors' calculations.

Note: Based on 1,939 observations. Standard errors, clustered at the strata level, are shown in parentheses. Coefficients as percentages of the mean in the control group are shown in brackets. P-values adjusted according to Anderson (2008) for the family of outcomes listed in the table. ***,*** indicate that the estimates coefficient has a statistically significant difference from zero at the $0.01,0.05$ and 0.01 levels, respectively. 
Table 6. Impact on benefits to other household members and transfers

\begin{tabular}{|c|c|c|c|}
\hline & $\begin{array}{l}\text { Mean in } \\
\text { control } \\
\text { group }\end{array}$ & $\begin{array}{c}\text { Difference } \\
\text { between } \\
\text { treatment and } \\
\text { control group }\end{array}$ & $\begin{array}{l}\text { Adjusted } \\
p \text {-values }\end{array}$ \\
\hline & (1) & (2) & (3) \\
\hline \multicolumn{4}{|l|}{ Panel A. Benefits for other household members } \\
\hline$\% \mathrm{HH}$ members age 3 to 15 enrolled in school ${ }^{\dagger}$ & 0.81 & $\begin{array}{l}-0.02 \\
(0.03)\end{array}$ & 0.360 \\
\hline Household size per adult equivalent & 2.87 & $\begin{array}{c}0.10 \\
(0.10)\end{array}$ & 0.190 \\
\hline \multicolumn{4}{|l|}{ Panel B. Transfer to household } \\
\hline Received private transfer in last 6 months & 0.22 & $\begin{array}{c}-0.08 \\
(0.03)^{* *}\end{array}$ & 0.025 \\
\hline \multicolumn{4}{|l|}{ Panel C. Transfer to and from older adult } \\
\hline Received transfer & 0.78 & $\begin{array}{c}-0.08 \\
(0.02)^{* * *}\end{array}$ & 0.009 \\
\hline Sent transfer & 0.24 & $\begin{array}{c}0.34 \\
(0.02)^{* * *}\end{array}$ & 0.001 \\
\hline
\end{tabular}

Source: Authors' calculations.

Note: Based on 1,939 observations. Standard errors, clustered at the strata level, are shown in parentheses. Coefficients as percentages of the mean in the control group are shown in brackets. P-values adjusted according to Anderson (2008) for the family of outcomes listed in the table. $* * *, * * *$ indicate that the estimates coefficient has a statistically significant difference from zero at the $0.01,0.05$ and 0.01 levels, respectively.

$\uparrow$ The proportion of households with no minors between the ages of 3 and 15 is 29 percent. This share is the same for beneficiary and non-beneficiary households $(\mathrm{p}=0.493)$. 


\section{Online Appendices}

\section{Appendix A. Definition of variables used in the tables}

Table A1. Definition of variables used in the tables

\begin{tabular}{|c|c|}
\hline Variable & Definition \\
\hline \multicolumn{2}{|l|}{ Panel A. Work last week } \\
\hline Worked & $\begin{array}{l}\text { Equals } 1 \text { if the older adult worked at least one hour during the } \\
\text { previous week. Equals } 0 \text { otherwise. }\end{array}$ \\
\hline Hours worked & Hours worked the previous week in the person's main occupation. \\
\hline \multicolumn{2}{|c|}{ Panel B. Paid work last week } \\
\hline Worked for pay & $\begin{array}{l}\text { Equals } 1 \text { if the older adult worked and reported a positive monetary } \\
\text { income. Equals } 0 \text { otherwise. }\end{array}$ \\
\hline Hours worked for pay & $\begin{array}{l}\text { Hours worked the previous week in the main occupation for which the } \\
\text { older adult reported a positive monetary income. }\end{array}$ \\
\hline Labor earnings & $\begin{array}{l}\text { Monthly monetary income, by main and secondary occupations, } \\
\text { expressed in US dollars conditional on working. The older adult may } \\
\text { be either employed or self-employed. }{ }^{1}\end{array}$ \\
\hline
\end{tabular}

Panel C. Physical health

Illness in the previous month

Perception of good or very good health (1 if yes, 0 otherwise)

Perception of difficulty with daily activities

Health insurance

Primary care visit

Visit, medication, or exam

Dental, ophthalmological, or optometric care or vaccination

Equals 1 if the older adult reports having at least one of the following health problems: persistent cough, headache, fever, sickness, lessions, pain when urinating, difficulty for chewing, diarrhea, relapse of a chronic disease, accident. Equals 0 otherwise.

Older adults' assessment of their health at the present time when given the options of very good, good, bad or very bad. Equals 1 if the response is very good or good. Equals 0 otherwise.

Older adults reporting difficulty with at least one of the following: walking from room to room, eating, bathing or showering, using the toilet, getting in or out of bed, or dressing. Variable equals 1 if yes and 0 if no.

Equals 1 if the older adult reports having public or private health insurance. Equals 0 otherwise.

Equals 1 if the older adult reports going to a primary care visit when having a health problem. Equals 0 otherwise.

Equals 1 if the older adult reports seeing a doctor, purchasing medication or test when having a health problem in the last month. Equals 0 otherwise.

Equals 1 if the older adult reports having dental, ophthalmological or optometric health care in the last 3 months. Equals 0 otherwise.

Surgery

Equals 1 if the older adult reports having hospitalized or surgery in the last year. Equals 0 otherwise.

Continued 
Table A1. Definition of variables used in the tables (continued)

\begin{tabular}{|c|c|}
\hline Variable & Definition \\
\hline \multicolumn{2}{|l|}{ Panel D. Well-being } \\
\hline Depression & $\begin{array}{l}\text { The index is based on a } 8 \text {-item yes/no questionnaire that contains } \\
\text { queries about whether one feels satisfied with life, whether one is } \\
\text { bored or lacks attention from other people, whether one prefers to } \\
\text { stay at home rather than going outside or feels full of energy, and so } \\
\text { on. The answers to each question are then compared with those } \\
\text { corresponding to a person with no trace of depression. Each opposite } \\
\text { answer is assigned a value of } 1 \text {. The Geriatric Depression Scale } \\
\text { (GDS) score is simply the sum of the points assigned to the answers } \\
\text { divided by the number of questions, with a higher score reflecting } \\
\text { the presence of more symptoms of depression. GDS used here was } \\
\text { developed by Sheikh and Yesavage (1986). }\end{array}$ \\
\hline \multirow[t]{13}{*}{ Satisfaction } & To construct this variable we used the following questions: \\
\hline & "How content are you... \\
\hline & With your health status? \\
\hline & With yourself? \\
\hline & With your ability to carry out daily activities? \\
\hline & With your interpersonal relations (neighbors, friends)? \\
\hline & With the place where you live? \\
\hline & With your relationship with your children? \\
\hline & With your relationship with other family members? \\
\hline & With your life in general?" \\
\hline & $\begin{array}{l}\text { The points for each question for the possible response options were } \\
\text { as follows: }\end{array}$ \\
\hline & Very content $=1 ;$ Content $=1 ;$ Not very content $=0 ;$ Not content $=0$. \\
\hline & $\begin{array}{l}\text { The score is the sum of the points for each question, divided by } \\
\text { eight. }\end{array}$ \\
\hline \multirow[t]{13}{*}{ Empowerment } & To construct this variable we used the following questions: \\
\hline & "Do you think... \\
\hline & $\begin{array}{l}\text { That your family takes you into account when making decisions on } \\
\text { household expenditures? }\end{array}$ \\
\hline & $\begin{array}{l}\text { That your family takes you into account when making important } \\
\text { decisions for the household? }\end{array}$ \\
\hline & That you support household expenditure? \\
\hline & That you decide freely about what to spend your money on? \\
\hline & That your family treats you with respect? \\
\hline & That your family respects your wishes, opinions and other \\
\hline & interests?" \\
\hline & $\begin{array}{l}\text { The points for each question for the possible response options were } \\
\text { as follows: }\end{array}$ \\
\hline & Always $=1 ;$ Yes, most of the time $=1 ;$ Sometimes $=0 ;$ Rarely $=0$ \\
\hline & Never $=0$ \\
\hline & The score is the sum of the points for each question, divided by six. \\
\hline
\end{tabular}


Table A1. Definition of variables used in the tables (continued)

\begin{tabular}{|c|c|}
\hline Variable & Definition \\
\hline Contribution & $\begin{array}{l}\text { To construct this variable, we used the following question: } \\
\text { "How much of your income do you contribute to household } \\
\text { expenditure in the household where you live?" } \\
\text { The values for this variable for the possible response options were as } \\
\text { follows: } \\
\text { All=1; Almost everything=1; More than half }=1 ; \text { Half }=1 ; \text { Less than } \\
\text { half }=1 ; \text { Not very much }=1 ; \text { No contribution=0; Has no income }=0 \text {. }\end{array}$ \\
\hline Self-worth & $\begin{array}{l}\text { To construct this variable, we used the following questions: } \\
\text { "Do you consider that you: } \\
\text { Provide economic support for the household? } \\
\text { Provide support by doing household chores (cleaning, cooking, etc.)? } \\
\text { Provide support in the form of childcare? } \\
\text { Support others with your advice and experience? } \\
\text { Represent a burden for the household?" (coding order reversed) } \\
\text { The points for each question for the possible response options were as } \\
\text { follows: } \\
\text { Always }=1 \text {, Sometimes }=1 \text {, Rarely }=0 \text {, Never }=0 \\
\text { The score is the sum of the points for each question, divided by five. }\end{array}$ \\
\hline Well-being & $\begin{array}{l}\text { The average of standardized scores for satisfaction, empowerment, } \\
\text { contribution and self-worth. We standardized each indicator according } \\
\text { to the distribution in the control group. All indicators had equal } \\
\text { weights. }\end{array}$ \\
\hline
\end{tabular}


Table A1. Definition of variables used in the tables (continued)

\section{Variable Definition}

Panel E. Household characteristics

Income per adult equivalent

Income per adult equivalent excluding older adults Household expenditure per adult equivalent

Household food expenditure per adult equivalent Household non-food expenditure per adult equivalent

Household size per adult equivalent

Age of head of household Married head of household Male head of household

Older adult head of household Education of head of household in years

Children in the household
Sum of labor income in the previous four weeks of all household members per adult equivalent in US dollars. ${ }^{1}$ See household size for the definition of adult equivalent.

Sum of labor income in the previous four weeks of all household members, excluding those aged 65 years or over, per adult equivalent in US dollars. ${ }^{1}$ See household size for the definition of adult equivalent. Expenditure in the previous four weeks on food and on non-food items in the household in US dollars. ${ }^{1}$

Expenditure in the previous four weeks on food and drink in or out of the household in US dollars. ${ }^{1}$

Expenditure in the previous four weeks in US dollars for household maintenance, transportation and communications, domestic services, entertainment and cultural activities, personal care, clothes and shoes, health, transfers, furniture and electronics, and other goods and services (funeral services, marriage services, etc.). ${ }^{1}$

Weighted sum of the number of household members. A weighting of 1 is given for persons older than 12 years and of 0.5 for persons 12 years old or younger.

Age of the head of household in years.

Equals 1 if the head of household is married or living with a partner. Equals 0 if the head of household is widowed, divorced, separated or single. Equals 1 if the sex of the head of household head is male. Equals 0 if the sex of the head of household is female.

Equals 1 if the head of household is 65 years old or older. Equals 0 otherwise.

Education of the head of household. Assigns the following values to the last year completed: initial education: 2 years, elementary education: 8 years, secondary or advanced non-university education: 13 years, university education: 17 years, graduate studies: 18 years. The years of education are calculated on the basis of the last education level successfully completed.

Equals 1 if there are household members between 5 and 13 years of age. Equals 0 otherwise.

Note: The exchange rate used to convert guaranis to dollars was $65,734.94$ per US\$1, which was the exchange rate in May of 2018 (Banco Central del Paraguay, 2020 [Retrieved 09/28/2020]). 
Table A1. Definition of variables used in the tables (continued)

Variable

Panel F. Enrollment

Percentage of household members from 3 to 15 years old enrolled in an educational institution
Definition

Number of household members from 3 to 15 years old enrolled in an educational institution, divided by the total number of household members between the ages of 3 and 15 . This value is missing for households without members in that age group.

Panel G. Current transfers to and from the household

Receipt of current transfers in the previous six months ( 1 if yes, 0 otherwise)

Receipt of current transfers in the previous six months excluding those to older adults (1 if yes, 0 otherwise)

Transfer expenditure in the previous 3 months ( 1 if any, 0 if none)
Transfers received in the previous six months in the form of alimony, pension transfers for food, remittances, survivor's pensions, JUNTOS program transfers and other transfers from public or private institutions. Pension 65 transfers are listed separately and are not included in the calculation of this variable. Only transfers to older adults are considered.

Transfers received in the previous six months in the form of alimony, pension transfers for food, remittances, survivor's pensions, JUNTOS program transfers and other transfers from public or private institutions. Pension 65 transfers are listed separately and are not included in the calculation of this variable. Only transfers to household members other than older adults are included.

Expenditures in the previous three months on tips to household members aged 14 or under, tips to non-household members, transfers, donations or gifts to family members not currently living in the household, periodic remittances to household members who live elsewhere, other expenditures, such as donations to institutions, church, charities, etc.

Source: Authors' calculations. 


\section{Appendix B. Map of beneficiary distribution across districts}

This appendix includes a map showing the location of beneficiaries in the country.

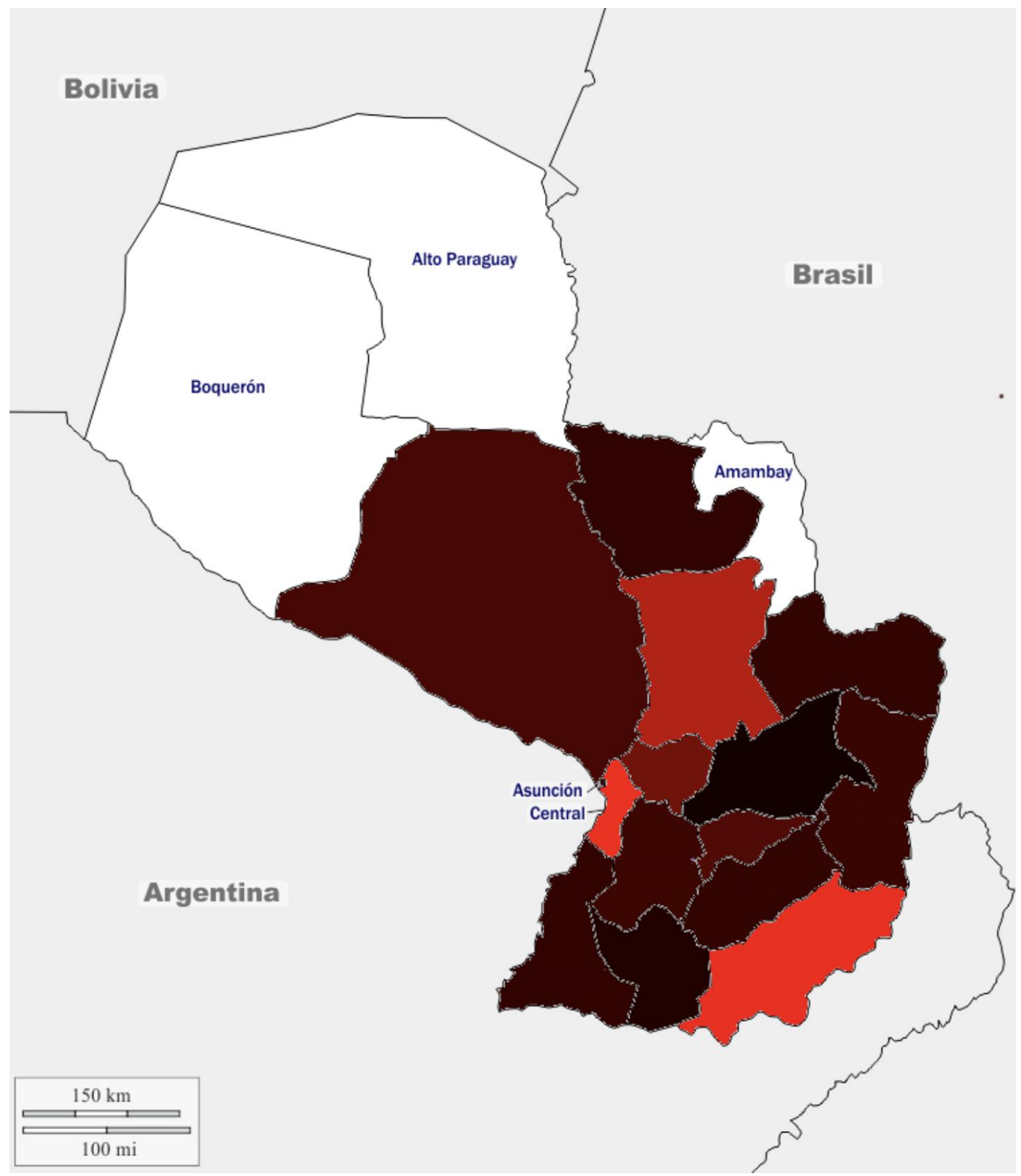

Figure B1. The departments show the distribution of beneficiaries across departments.

Departments in brighter red represent those with the highest share of beneficiaries and those with darker shade the lowest share (Share ranged from 1 to 20 percent). The departments of Boquerón, Alto Paraguay, and Amambay were not sampled because less than 1 percent of the beneficiary population resided in these departments.

Source: Authors' calculations. 


\section{Appendix C. Comparison of households included and those excluded from analysis}

Table $\mathbf{C 1}$ shows the number of households according to their inclusion in the different stages that defined the evaluation sample. The program targeted 3,000 potential beneficiaries out of which 2,968 were identified and needs were assessed to confirm eligibility for the program. Out of those, a total of 2,473 potential beneficiaries received visits and information was collected. Out of those, a total of 1,939 potential beneficiaries provided information which could be used for evaluation.

Table $\mathbf{C 2}$ shows estimates for differences among those individuals in the surveyed sample but excluded from the evaluation and those in the evaluation sample. Such tests allow us to assess if the lack of information of excluded potential beneficiaries would result in a biased sample. The first column shows the average of characteristics both for older adults and household heads among the 1,939 older adults included in the sample. The second column shows averages among the 534 older adults excluded. The thirds column shows average differences. The fourth column lists p-values for tests of differences in means between the two groups. Overall, we find no statistically significant differences at the 10 percent confidence level.

We conclude that any exclusions resulting from the lack of data is unlikely to bias the sample.

\section{Table C1. Number of individuals per sample}

\begin{tabular}{lccc}
\hline & Control & Treatment & Total \\
\hline Targeted sample & 1,491 & 1,477 & 2,968 \\
Surveyed sample (83 percent of the targeted sample) & 1,294 & 1,179 & 2,473 \\
Evaluation sample (65 percent of the targeted sample) & 1,021 & 918 & 1,939 \\
\hline
\end{tabular}

Source: Authors' calculations. 
Table C2. Means of households included in and excluded from the analysis

\begin{tabular}{|c|c|c|c|c|}
\hline & $\begin{array}{c}\text { Included } \\
\text { (A) }\end{array}$ & $\begin{array}{c}\text { Excluded } \\
\text { (B) }\end{array}$ & $\begin{array}{l}\text { Difference } \\
(\mathrm{C})=(\mathrm{A})-(\mathrm{B})\end{array}$ & $\begin{array}{l}p \text {-value for test } \\
\text { of equality } \\
\text { (D) }\end{array}$ \\
\hline \multicolumn{5}{|l|}{ Panel A. Older adult characteristics } \\
\hline Age & 65.47 & 65.14 & $\begin{array}{c}0.12 \\
(0.54)\end{array}$ & 0.826 \\
\hline Male & 0.72 & 0.70 & $\begin{array}{c}0.01 \\
(0.02)\end{array}$ & 0.744 \\
\hline Married & 0.41 & 0.41 & $\begin{array}{c}0 \\
(0.02)\end{array}$ & 0.967 \\
\hline Literate & 0.46 & 0.46 & $\begin{array}{l}-0.01 \\
(0.01)\end{array}$ & 0.570 \\
\hline Years of schooling & 3.77 & 4.14 & $\begin{array}{l}-0.15 \\
(0.08)\end{array}$ & 0.108 \\
\hline \multicolumn{5}{|c|}{ Panel B. Household head characteristics } \\
\hline Age & 72.70 & 72.75 & $\begin{array}{c}0.11 \\
(0.39)\end{array}$ & 0.796 \\
\hline Male & 0.39 & 0.39 & $\begin{array}{l}-0.01 \\
(0.01)\end{array}$ & 0.550 \\
\hline Married & 0.70 & 0.73 & $\begin{array}{l}-0.02 \\
(0.02)\end{array}$ & 0.271 \\
\hline Years of schooling & 2.09 & 2.17 & $\begin{array}{l}-0.03 \\
(0.05)\end{array}$ & 0.562 \\
\hline There is children in the household & 0.28 & 0.30 & $\begin{array}{l}-0.02 \\
(0.01)\end{array}$ & 0.314 \\
\hline Observations & 1,939 & 534 & & \\
\hline
\end{tabular}

Source: Authors' calculations. Note: Standard errors are clustered at the strata level and shown in parenthesis. 
Table C3. Impact on individual labor supply

\begin{tabular}{|c|c|c|c|}
\hline & $\begin{array}{c}\text { Estimation based } \\
\text { on the evaluation } \\
\text { sample } \\
\text { (1) }\end{array}$ & $\begin{array}{l}\text { Estimation based } \\
\text { on the surveyed } \\
\text { sample } \\
\text { (2) }\end{array}$ & $\begin{array}{l}\text { P-value for the } \\
\text { difference of } \\
\text { means } \\
\text { (1) and (2) } \\
\text { (3) }\end{array}$ \\
\hline \multicolumn{4}{|l|}{ Panel A. Work } \\
\hline Worked & $\begin{array}{c}0.03 \\
(0.02)\end{array}$ & $\begin{array}{c}0.01 \\
(0.02)\end{array}$ & 0.521 \\
\hline Hours worked & $\begin{array}{l}-0.30 \\
(0.56)\end{array}$ & $\begin{array}{c}0.20 \\
(0.52)\end{array}$ & 0.506 \\
\hline \multicolumn{4}{|c|}{ Panel B. Paid work last week } \\
\hline Worked & $\begin{array}{c}-0.04 \\
(0.01)^{* * *}\end{array}$ & $\begin{array}{c}-0.04 \\
(0.01)^{* *}\end{array}$ & 0.832 \\
\hline Hours worked & $\begin{array}{c}-1.21 \\
(0.52)^{*}\end{array}$ & $\begin{array}{c}-0.95 \\
(0.43)^{*}\end{array}$ & 0.700 \\
\hline Labor earnings & $\begin{array}{c}3.88 \\
(5.18)\end{array}$ & $\begin{array}{c}4.07 \\
(5.59)\end{array}$ & 0.981 \\
\hline Observations & 1,939 & 2,473 & \\
\hline
\end{tabular}

Source: Authors' calculations.

Note: Estimates for Column (1) are based on the surveyed sample. Estimates for Column (2) are based on the subset of districts for which attrition did not threat the experimental design. Standard errors, clustered at the strata level, are shown in parentheses. $* * *, * * *$ indicate that the estimates coefficient has a statistically significant difference from zero at the $0.01,0.05$ and 0.01 levels, respectively. 
Table C4. Impact on health and well-being

\begin{tabular}{|c|c|c|c|}
\hline & $\begin{array}{c}\text { Estimation based } \\
\text { on the evaluation } \\
\text { sample } \\
\text { (1) }\end{array}$ & $\begin{array}{l}\text { Estimation based } \\
\text { on the surveyed } \\
\text { sample } \\
\text { (2) }\end{array}$ & $\begin{array}{l}\text { P-value for } \\
\text { the } \\
\text { difference of } \\
\text { means } \\
\text { (1) and (2) } \\
\text { (3) }\end{array}$ \\
\hline \multicolumn{4}{|l|}{ Panel A. Physical health } \\
\hline Illness in the last 6 months & $\begin{array}{c}-0.06 \\
(0.02)^{* * *}\end{array}$ & $\begin{array}{c}-0.08 \\
(0.02)^{* * * *}\end{array}$ & 0.582 \\
\hline \multicolumn{4}{|c|}{ Panel B. Mental health and subjective well-being } \\
\hline Depression symptoms index & $\begin{array}{c}-0.04 \\
(0.01)^{* * *}\end{array}$ & $\begin{array}{c}-0.04 \\
(0.01)^{* * * *}\end{array}$ & 0.599 \\
\hline Satisfaction with quality of life & $\begin{array}{c}0.05 \\
(0.01)^{* * *}\end{array}$ & $\begin{array}{c}0.05 \\
(0.01)^{* * *}\end{array}$ & 0.937 \\
\hline Empowerment & $\begin{array}{c}0.12 \\
(0.02)^{* * *}\end{array}$ & $\begin{array}{c}0.11 \\
(0.02)^{* * *}\end{array}$ & 0.833 \\
\hline Contribution & $\begin{array}{c}0.45 \\
(0.03)^{* * *}\end{array}$ & $\begin{array}{c}0.46 \\
(0.03)^{* * *}\end{array}$ & 0.890 \\
\hline Self-worth & $\begin{array}{c}0.10 \\
(0.01)^{* * *}\end{array}$ & $\begin{array}{c}0.11 \\
(0.01)^{* * *}\end{array}$ & 0.670 \\
\hline Subjective well-being index & $\begin{array}{c}0.48 \\
(0.03)^{* * *}\end{array}$ & $\begin{array}{c}0.49 \\
(0.04)^{* * *}\end{array}$ & 0.870 \\
\hline Memory & $\begin{array}{c}0.24 \\
(0.09)^{* *}\end{array}$ & $\begin{array}{c}0.25 \\
(0.08)^{* *}\end{array}$ & 0.920 \\
\hline Observations & 1,939 & 2,473 & \\
\hline
\end{tabular}

Source: Authors' calculations.

Note: Estimates for Column (1) are based on the surveyed sample. Estimates for Column (2) are based on the subset of districts for which attrition did not threat the experimental design. Standard errors, clustered at the strata level, are shown in parentheses. $* * *, * * *$ indicate that the estimates coefficient has a statistically significant difference from zero at the $0.01,0.05$ and 0.01 levels, respectively. 
Table C5. Impact on household income and expenditures

\begin{tabular}{|c|c|c|c|}
\hline & $\begin{array}{l}\text { Estimatio } \\
\mathrm{n} \text { based on } \\
\text { the } \\
\text { evaluation } \\
\text { sample } \\
\text { (1) }\end{array}$ & $\begin{array}{l}\text { Estimation } \\
\text { based on the } \\
\text { surveyed } \\
\text { sample } \\
\text { (2) }\end{array}$ & $\begin{array}{l}\text { P-value for the } \\
\text { difference of } \\
\text { means } \\
\text { (1) and (2) } \\
\text { (3) }\end{array}$ \\
\hline Labor income per adult equivalent (AE) & $\begin{array}{c}2.31 \\
(56.23)\end{array}$ & $\begin{array}{c}0.78 \\
(5.11)\end{array}$ & 0.850 \\
\hline Labor income per AE excluding older adult & $\begin{array}{c}2.66 \\
(6.58)\end{array}$ & $\begin{array}{l}-0.42 \\
(5.05)\end{array}$ & 0.710 \\
\hline Household expenditure per AE & $\begin{array}{c}25.25 \\
(2.04)^{* * *}\end{array}$ & $\begin{array}{c}25.51 \\
(1.55)^{* * * *}\end{array}$ & 0.917 \\
\hline Household food expenditure per AE & $\begin{array}{c}17.37 \\
(1.89)^{* * *}\end{array}$ & $\begin{array}{c}18.13 \\
(1.92)^{* * * *}\end{array}$ & 0.778 \\
\hline Household non-food expenditure per AE & $\begin{array}{c}7.87 \\
(1.71)^{* * *}\end{array}$ & $\begin{array}{c}7.38 \\
(1.39)^{* * *}\end{array}$ & 0.822 \\
\hline Observations & 1,939 & 2,473 & \\
\hline
\end{tabular}

Source: Authors' calculations.

Note: Estimates for Column (1) are based on the surveyed sample. Estimates for Column (2) are based on the subset of districts for which attrition did not threat the experimental design. Standard errors, clustered at the strata level, are shown in parentheses. $* * *, * * *$ indicate that the estimates coefficient has a statistically significant difference from zero at the $0.01,0.05$ and 0.01 levels, respectively. 